\title{
Transformation of Higher Education Policies in the Context of the Industrial Revolution 4.0*
}

Kenan ÖZCAN, ${ }^{*}$ Aydın BALYER ${ }^{* *}$

- Received: 05.05.2020 • Accepted: 26.03.2021 • Online First: 12.04.2021

\begin{abstract}
Universities are expected to have leading roles to increase their global competitiveness by adapting themselves to the 4.0 industrial revolution. In order to conduct these roles, they need to transform their policies in education, teaching, research, and product development. Therefore, this study aims to determine what policy transformation universities need to catch the 4.0 industrial revolution regarding education-instruction, technical infrastructure, and administrative structures. The research was designed with a qualitative phenomenological method. The participants consisted of 15 faculty members who had post-graduate degrees or served at a university abroad for a while. They were determined by using a purposeful sampling method. The data were gathered with a semi-structured interview technique and analyzed with the inductive analysis method. Research results showed that universities need major policy shifts to train human resources needed by the 4.0 industrial revolution in Turkey. Also, it was discovered that the physical capacity of classrooms, libraries, and laboratories is insufficient according to the number of students and the curriculum is generally theory-based, and course contents are very intensive.
\end{abstract}

Keywords: 4.0 industrial revolution, 21 st-year skills, higher education, education policies.

\section{Cited:}

Özcan, K. \& Balyer, A. (2021). Transformation of higher education policies in the context of the industrial revolution 4.0. Pamukkale University Journal of Education, 53, 261-279.doi: 10.9779/pauefd.732724.

\footnotetext{
* A part of this research was presented at VIth International Eurasian Educational Research Congress held on 19-22 June 2019 at Ankara Üniversity.

* Prof. Dr. Adıyaman Üniversitesi, ORCID: 0000-0002-2106-0972, kozcan04@hotmail.com

** Doç. Dr. Yıldız Teknik Üniversitesi, ORCID: 0000-0003-1784-2522, balyer@yildiz.edu.tr
} 


\section{Introduction}

With the 4.0 industrial revolution, information has transformed into digital and autonomous technologies. This transformation leads to new forms of social relationships. In this process, as power is gathered, many things are discussed like standardization, synchronization, central management units, energy, money, and production relations (Toffler, 2008). Smart machines abandoned the production sector, and the services sector becomes prominent (Yazıc1 \& Düzkaya, 2016). The determinant of this period is the transformation of new information and methods produced into technology, which is easier, cheaper, and richer than the previous periods. However, there is no recipe for adopting an educational philosophy and methods to develop new knowledge and practice. On the other hand, strengthening technological infrastructure and creating an environment can transform knowledge into practice. Therefore, there is a need to increase the expenditures per person in education. However, today, with the effect of neoliberal policies, public education expenditures are decreasing gradually, adapting universities to the Industrial Revolution 4.0 on of the concept require increased financial support from the government.

Universities are expected to have leading roles to increase their global competitiveness by adapting themselves to the 4.0 industrial revolution. In order to conduct these roles, they need to transform their policies in education, teaching, research, and product development.

According to Carl (2009), the development of industrialization and the quality of education realize together. Before the industrialization process, the formal enrollment rate was low. From antic Greece to the Industrial revolution, only male children of wealthy families could benefit from educational services, and families financed this service. Education helped children improve themselves and earn their wealth. As a result, the importance of education was reconsidered. This led to donations from wealthy families to increase the schooling rate (Katz, 1987). This resulted in the development of the national economy in the 20th century (Grubb \& Lazerson, 2004).

Parallel to evolving to the 4.0 industrial revolution in education, 4.0 approaches are now on the agenda. When it comes to higher education, this transformation forces higher education institutions to develop new strategies to prepare their students for new business areas where competition is intense; in this context, important pressures are increasing, especially on universities from different sectors in the information age in order to teach the 21st-century skills (Önday, 2017; Penprase, 2018; TÜSİAD, 2016). Regarding education 
K. Özcan, A. Balyer / Pamukkale University Journal of Education, 53, 261-279, 2021

4.0, the basic 21st-century skills are critical thinking and problem solving, communication and collaboration, creativity and innovation, initiative and self-direction, social, intercultural skills, leadership and responsibility, productivity, accountability, media literacy, Information and Communication Technologies (ICT). In order to teach these skills to students, it is expected to construct a modern curriculum in higher education, learning implementations should be restructured, and a participatory management structure should be formed.

This study aims to determine what policy transformation universities need to catch the 4.0 industrial revolution regarding education-instruction services, technical infrastructure, and forming administrative structures and administrator competencies. In order to reach the general purpose of the research, the answers to the following questions were researched.

- What are the faculty members' views on access to information and technology in higher education institutions?

- What are the faculty members' views on the education and instructing services in higher education institutions?

- What are the faculty members' views on the student activities in higher education institutions?

- What are the faculty members' views on forming administrative structures and administrator competencies in higher education institutions?

\section{Method}

The research employed a phenomenological research design. Phenomenological researches are conducted to find out how a concept or a phenomenon is experienced and understood by individuals (Creswell, 2007; Yıldırım \& Şimşek, 2011). These kinds of researches are also used to gain in-depth knowledge in a study (Denzin \& Lincoln, 2005; Marshall \& Rossman, 2006; McMillan, 2000: 45). Phenomenological approaches also suggest that participants should be regarded as individuals to create their meanings in the social environment in which they live, the relations they have established, and they are re-creators of their social worlds with their subjectivity (Balc1, 2015; Büyüköztürk, Kılıç Çakmak, Akgün, Karadeniz \& Demirel, 2008, 151; Kümbetoğlu, 2005; Punch, 2005). They describe phenomenological approaches as investigating one or more situations and analyzing the data related to the situation with a holistic approach. In this study, the data were collected using a semistructured interview. As Karasar (2007) stated, "this method is neither as rigid as fully structured interviews nor flexible as unstructured interviews." 


\section{Study Group}

The participants of the research consisted of 15 academicians who work in different universities at Istanbul University, Y1ldı Technical University, Adiyaman University, Mehmet Akif Ersoy University, Pamukkale University, Muş Alpaslan University, Medeniyet University, and Gazi University. The participants were determined by using a purposeful sampling method. Out of the participants, 4 of the faculty members are female, 11 are male, and 28-52 years old. The average duration of the interview with each faculty member took 40-55 minutes. Moreover, other demographic variables are given in table 1.

Table 1. Demographics of the participants

\begin{tabular}{|c|c|c|c|c|}
\hline Nick Names & Field & Title & $\begin{array}{c}\text { Purpose of } \\
\text { Visit }\end{array}$ & $\begin{array}{c}\text { Country } \\
\text { Distribution }\end{array}$ \\
\hline Metin & Computer Eng. & Dr. Res. Ast. & $\mathrm{PhD}$ & USA \\
\hline Osman & Science & Lecturer & P.Doc. & USA \\
\hline Turgay & Physics & Prof. Dr. & P.Doc. & Switzerland \\
\hline Elif & Psych.Couns.and Guid. & Lecturer & $\mathrm{PhD}$ & USA \\
\hline Umut & Philosophy & Lecturer & $\mathrm{PhD}$ & USA \\
\hline Ebru & Special education & Lecturer & $\mathrm{PhD}$ & USA \\
\hline Selçuk & Industrial Engineering & Assoc. Prof & P.Doc. & USA \\
\hline Arda & Civil Engineering & Assoc. Prof & $\mathrm{PhD}$ & USA \\
\hline Muhammed & Educational Management & Assoc. Prof & $\mathrm{PhD}$ & USA \\
\hline Şenay & Curriculum and Instruction & Lecturer & $\mathrm{PhD}$ & USA \\
\hline Ozan & Math & Dr. Res. Ast. & $\mathrm{PhD}$ & USA \\
\hline Gülsen & Biology & Lecturer & P.Doc. & USA \\
\hline Ahmet & Chemistry & Assoc. Prof & $\mathrm{PhD}$ & USA \\
\hline Cemal & Measurement and Assessment & Lecturer & $\mathrm{PhD}$ & USA \\
\hline Ard1l & Mechanical Engineering & Prof. Dr. & Post. Doc. & USA \\
\hline
\end{tabular}

In Table 1, the participants' demographics are presented. According to it, the participants work in 14 different fields. Out of them, 2 are research assistants, 7 of them are 
lecturers. Four of them are associate professors, and 2 of them are professors. Out of them, 5 were visited those countries for their post-doc researches, and 10 for their doctorate education. As for country distribution, 1 participant was in Switzerland, and 14 were in the USA. The average duration of stay was between 1-8 years.

Data Analysis

The data of this research were analyzed by using the inductive analysis method. Such analyzes are generally used to gather, analyze and interpret similar data collected on a subject (Büyüköztürk et al. 2008; Mayring, 2000; Yıldırım \& Şimşek, 2011). Inductive analysis is carried out to reveal the underlying concepts and the relationships between them by coding (Miles \& Huberman, 1994; Y1ldırım \& Şimşek 2011). The codings of these two researchers' similarities were found as $90 \%$. The analysis of this research data was carried out in three stages. In the first stage, the data obtained as the audio recording was compared with the data obtained in writing. In the second stage, the researcher and another faculty member experienced in qualitative research coded the written data separately. In the third stage, the data were gathered.

\section{Findings}

In this part, the data obtained through this research are presented systematically regarding the participants' views on information and use of technology, education and instruction services, student activities, and forming administrative structures and administrator competencies in higher education institutions. First of all, the participants' views on information technologies and the use of technology are given in table-2. 
Table 2. The participants' views on access to information and use of technology

\begin{tabular}{|c|c|c|}
\hline Theme & Sub-Themes & Codes \\
\hline \multirow{22}{*}{ 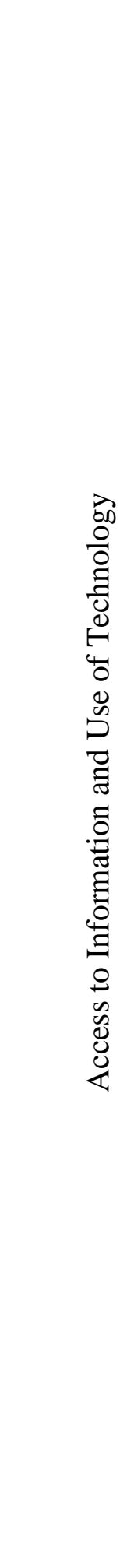 } & \multirow{9}{*}{ Library } & Insufficient capacity \\
\hline & & The low number of books \\
\hline & & Media diversity limited \\
\hline & & Access to database limited \\
\hline & & No movies and documentaries \\
\hline & & Poor Wi-Fi \\
\hline & & Open only day time \\
\hline & & No daily newspapers \\
\hline & & Periodicals limited \\
\hline & \multirow{6}{*}{$\begin{array}{l}\text { Classroom Environment and } \\
\text { Hardware }\end{array}$} & Column type seating arrangement \\
\hline & & Ergonomic problems \\
\hline & & Interactive board \\
\hline & & Projection \\
\hline & & Computer \\
\hline & & Internet \\
\hline & \multirow{7}{*}{ Laboratory Infrastructure } & Limited activity \\
\hline & & Old technology \\
\hline & & Faulty Devices \\
\hline & & Limited use \\
\hline & & Insufficient material \\
\hline & & Insufficient Capacity \\
\hline & & Calibration problem \\
\hline
\end{tabular}


In Table 2, the participants' views on access to information and use of technology were analyzed below three sub-themes: library, classroom environment, and hardware laboratory infrastructure at university. Participants stated that although the library has a central location, the physical capacity of the library is insufficient according to the number of students. They also underlined that diversity of working environment (e.g., single, group, teamwork, quiet, access to electronic information and comfort features, etc.), several books, and $a$ variety of publications are limited. Also, the library is open only at daytimes. In addition, they noted that the access to the electronic database in the library is limited, the number of computers for students is insufficient, and wireless internet (Wi-Fi) is poor. Visual and audio (film and documentary etc.) resources, periodical newspapers, various magazines, and CD media resources are also limited. A participant said, "Our university is 15 years old, but there is no library building on our campus. Instead, there is a unit where students can borrow books from (Metin)." Another academician emphasized, "The university I visited for my studies in the USA had more than a million books. It was possible to access resources 24 hours a day, except for national and religious holidays (SSenay)." Having an accessible library for students and academic staff both physically and electronically is essential today to reach knowledge. "Libraries must be integrated for all students all around the world. Students who cannot access any kind of printed researchers and printed books can reach at least a softcopy of them (Osman)." In addition, libraries should be designed with a high physical capacity and allow students to work individually or in groups. They should also have access to a rich database as well as printed resources. Moreover, libraries should be designed as multi-level learning centers where many activities can be held.

Furthermore, according to the participants, there are some problems regarding the classroom environment and hardware. They stated that an interactive board, computer and projection machine, and internet access are important to increase efficiency in the classrooms. Also, the classroom settings, ergonomic conditions are important to have an interactive lesson. However, the participants underlined that technology in the classroom could not be used effectively in practice. A lecturer claimed, "Programs that support the teaching process are not installed on the interactive board. Therefore, we can only use it as a projection machine (Osman)". Another academician confessed, "Although collaborative learning is essential in classrooms, here we have an individual seating arrangement design in the classroom (Ozan)." Another faculty member said, "There is internet access in the classroom, but I cannot use it during my lesson due to the technical problems. We cannot 
reach people who are in charge with technical problems (Elif)". A lecturer mentioned, "Although there are many applications on the interactive board, it is not possible to use it as we have not been trained about it (Umut).

The faculty members stated that the classrooms are designed with a column style, which negatively affects teamwork and limits interaction and informal learning. A lecturer who completed his Ph.D. in the USA drew attention to the importance of the class design and said, "I cannot prepare contents that require interaction because of this classroom design. I prefer didactic teaching method (Ozan)". Another faculty member noted, "... At our university, lessons are delivered in an atmosphere that resembles the ones used during the First Industrial Revolution Ebru)." In general, it can be inferred from their views that this type of classroom design can only be used for teacher-centered teaching methods. Hence, there is a need for a new and contemporary classroom design that allows interaction. In such a classroom environment, a synergy can be created, free thoughts are expressed, high communication skills are observed, and teamwork is implemented.

Furthermore, a strong laboratory infrastructure is also important for a university, and almost all participants stressed its importance. However, most participants underlined that the laboratory capacity is limited according to the number of students, the technology is old, some devices are faulty, and the correct measurements cannot be made due to the calibration problem. Also, consumables cannot be obtained due to financing problems. In this regard, a participant stated, "Some laboratory machines cannot be used due to the planning and technical personnel problems. A CNC machine was bought for 80.000 TL to the workshop, but there is no staff to use it (Ardil)." Another academician said, "Although I spoke to the faculty administrators many times, the laboratory has 40 computers, but students cannot access properly (Mohammed)." A faculty member underlined, "There are faculty members in our department who do not use the mail system and interactive board effectively (Ahmet).")." On the other hand, another academician said, "I asked the engineering faculty students to do the homework and send it to me, they asked how to send it. I was surprised at it. Their technology literacy is poor. Therefore, they insist on assigning papers (Metin). " In this regard, providing students with computers and helping them overcome their digital literacy problems by giving them robotic coding skills may contribute to access to information and use it properly.

In Table 3, the participants' views can be seen. Participants stated that the curriculum is generally delivered theory-based, and there is little room for practice. A participant said, 
K. Özcan, A. Balyer / Pamukkale University Journal of Education, 53, 261-279, 2021

"I have difficulties in finishing the textbook in fourteen weeks. I have to cover all the units. Therefore, we have little time left to practice (Cemal)." Another faculty member noted, "We have 2 hours allocated for the Educational Sociology course. The coursebook we follow has more than 46 chapters and more than 500 pages. It is impossible to cover most topics (Muhammed)." A lecturer added, "Teacher candidates take scientific research lessons. It is essential to improve research skills. The classes are crowds, the class hour is low, and it is hard to teach them the basic topics, too" (Cemal)."

Table 3. Participants' views on education and instruction services

\begin{tabular}{|c|c|c|}
\hline Theme & Sub-Themes & Codes \\
\hline \multirow{16}{*}{ 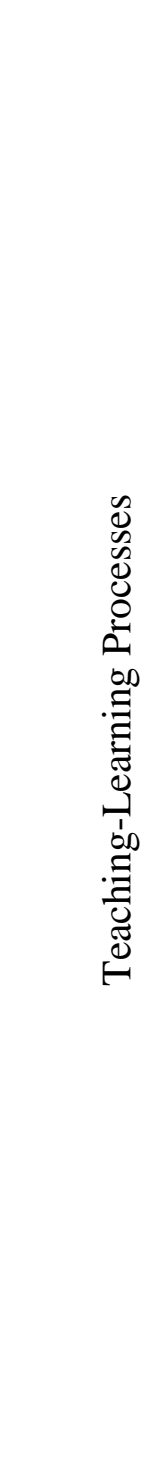 } & & Theory-based \\
\hline & Teaching program & Intensive \\
\hline & & Limited practice \\
\hline & & Teacher-centered \\
\hline & Teaching Methods & Didactic \\
\hline & & Demonstration method \\
\hline & & Limited practice \\
\hline & & Insufficient internship period \\
\hline & Hactice & Inadequate patent production \\
\hline & & No economic return \\
\hline & & Generally passive \\
\hline & & Unprepared \\
\hline & Student participation & Limited class participation \\
\hline & & Limited interaction \\
\hline & & No teamwork \\
\hline & & Inadequate informal learning \\
\hline
\end{tabular}

What is more, according to the participants, the courses are generally theory-based and teacher-centered. As for the teaching methods, they prefer didactic teaching methods, 
which are generally supported by slides. An academician expressed, "During the classes, usually teachers talk, and students listen, and the participation is very limited (Umut)." An academic said, "In fact, to transfer the knowledge into real life practices, they have to be involved in the course in any way, which requires interactive teaching methods in the classroom (Elif)." Another faculty member claimed, "In the USA, teaching methods and techniques, classroom management, measurement and evaluation, preparing lesson plans, statistics programs are taught for all faculty members. The lectures are recorded, examined by a specialist group, and feedback is given to the lecturer (Ozan)."

Participants stated that the laboratories and drama halls in the units were insufficient to transform the theoretical knowledge given in the courses into practice, the practical training of the student internship done in the enterprises was not given enough importance, the students were employed in less important and bring-and-take jobs, and the on-the-job training processes were ignored.

Moreover, the participants explained that the laboratories and drama halls are insufficient. Indeed, they are crucial to transform the theoretical knowledge given in the courses into practice. Also, during the internship periods, students are not given much chance to do the practice. An academician noted, "The duration and class hours of the teaching internship is short, and they should be increased" (Şenay)." Another lecturer emphasized, "Sometimes engineering students hand in fake internship reports (Arda)." One of the most important problems of the Turkish education system is the theory-practice balance. This balance cannot be provided, and little room is provided for practice.

Regarding student participation, the participants' views are generally negative. They claim that very few students participate in the class by expressing their opinions and asking questions. A lecturer noted, "In each class, eight or ten students are active, the others are listening passively (Gülsen)." Furthermore, the participants think that students generally come to the classroom unprepared and remain passive there with limited cooperation. This may stem from the classroom setting because classroom designs do not allow interaction. Therefore, a collaborative learning environment becomes a utopia. Hence, in education 4.0, there should be a collaborative learning environment, and students should participate in the lesson actively. Only in this case, students can develop twenty-first-century skills. 
Table 4. The participants' views on student activities

\begin{tabular}{|c|c|c|}
\hline Theme & Sub-Themes & Codes \\
\hline \multirow{27}{*}{ 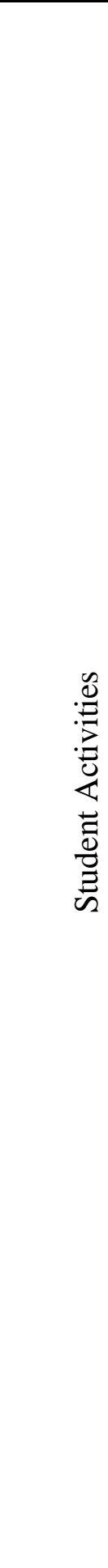 } & \multirow{8}{*}{ Socio-cultural } & Few Student communities \\
\hline & & Low Student attendance \\
\hline & & Insufficient funding \\
\hline & & Special days/weeks are celebrated \\
\hline & & Spring festivals are held \\
\hline & & No idea and thought clubs \\
\hline & & Limited Management support \\
\hline & & Secret and open censorship \\
\hline & \multirow{7}{*}{ Sport } & Event space is limited \\
\hline & & The number of licensed athlete students is low \\
\hline & & No incentive \\
\hline & & Branch diversity limited \\
\hline & & No coach \\
\hline & & Insufficient funding \\
\hline & & Extreme sports limited \\
\hline & \multirow{7}{*}{ Art } & Music groups are not formed \\
\hline & & No studio infrastructure \\
\hline & & Amphitheater inadequate \\
\hline & & There is a poetry club \\
\hline & & The theater club is not active \\
\hline & & No painting workshops \\
\hline & & The number of educators is limited \\
\hline & \multirow{5}{*}{ Scientific activities } & Limited \\
\hline & & No incentive \\
\hline & & No funding \\
\hline & & Competition is limited \\
\hline & & The technical infrastructure is insufficient \\
\hline
\end{tabular}

In Table 4, the participants' views on student activities are shown. According to these views, in general, student communities, clubs, and similar organizations are insufficient. Therefore, their participation is limited. A lecturer said, "It is important for students to be 
members of a club or activity for their socialization. However, at our university, as clubs and their activities are very limited, very few students can participate in them (Ahmet)." The problem is probably because of financial constraints, institutional culture, and traditions of the university. "Our students are not encouraged to join the communities. These clubs do not have a budget and support (Elif)." Every student needs to be encouraged to participate in these activities, but physical scarcity prevents them from doing it. An academic said, "I know at most 2 or 3 students who have licenses in a sports field in each class. I encourage them to do sports, and they also want. However, the campus environment is not suitable. Compared to the central campus, there are limited sports fields on our small campus (Osman)". Another lecturer mentioned, "A 6-km bike path was built last year. From now on, they will be to take advantage of this opportunity. Students could use all kinds of sports fields at the university abroad, from table tennis to football for free (Arda)."

Considering the art events, the participants think that there are difficulties in the development of cultural and artistic infrastructure due to the financial problems at universities. In this regard, technical infrastructure (studio, theater and student center, etc.) and equipment capacity seem insufficient. One faculty member stated, "Art is important to develop creative thinking skills. Students should be taught in art as much as science (Turgay)". The participants underlined the roles of artistic and cultural facilities in developing creative thinking skills. Performing scientific activities at universities may contribute to the development of students' analytical thinking skills as well. It is possible only by establishing technical infrastructure. Another faculty member stated, "... in order for positive science to develop, students should be provided with opportunities to deal with art, sports, and literature (Umut)". 
Table 5. The participants' views on administrative structures and competencies

\begin{tabular}{|c|c|c|c|c|c|}
\hline Theme & & & Sub-Themes & & Codes \\
\hline \multirow{7}{*}{ 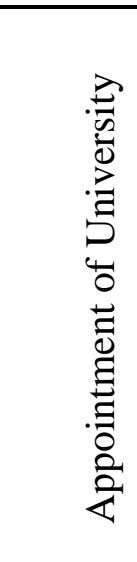 } & \multirow{7}{*}{\multicolumn{2}{|c|}{ 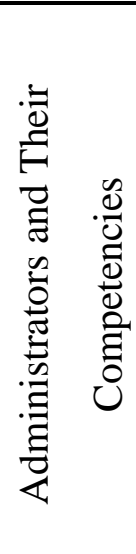 }} & Appointing & An & Political \\
\hline & & & \multirow{2}{*}{\multicolumn{2}{|c|}{ Administrator }} & No universal criteria \\
\hline & & & & & The criteria are uncertain \\
\hline & & & Administrative & & Has a leadership qualification \\
\hline & & & \multirow[t]{3}{*}{ Competencies } & & Communication is strong \\
\hline & & & & & Governance culture weak \\
\hline & & & & & $\begin{array}{l}\text { Limited knowledge of } \\
\text { management theory }\end{array}$ \\
\hline
\end{tabular}

In Table 5, the participants' views on administrative structures and administrators' competencies are presented. The participants generally think that rectors or the other midmanagers are appointed without considering their administrative competencies. In this regard, they are mostly appointed with political considerations. There are no certain criteria to be a rector. One of the faculty members stated, "... the lack of clear and democratic principles in the appointment of rectors causes politicians to intervene in education and science policies at university (Mohammed)." Faculty members' opinions are not taken anymore while appointing a rector. The rectors are also not asked whether they have experience or certificates in the educational administration field. For this reason, their chance of success is naturally low. Another faculty member expressed, "The cancellation of the voting rights of the faculty members during the election of the rector candidates caused rectors to remain insensitive to demands of academicians. They are sensitive to the president's demand, which decreased motivation and institutional commitment. This leads to organizational silence (Ebru)".

Most participants believe that rectors generally demonstrate autocratic leadership behaviors. They are trying to create an entrepreneurial university, but there is a significant distance to be taken. An academic said, "Our rector prefers to work with a team close to his political view rather than merit (Ardil) ..." Another faculty member explained, "...in order to determine the right policy and make decisions that will carry the university to the future, rectors should adopt a participatory management approach. However, our rector is managing the university with a narrow group (Muhammed)." 


\section{Discussion}

Education plays an important role in the development of societies socially, culturally, and economically. In this regard, countries that have established a strong and scientific education system are considered to meet the Industrial Revolution 4.0. The 4.0 Industrial Revolution requires certain competencies such as critical thinking and problem solving, communication and collaboration, creativity and innovation, initiative and self-direction, social, intercultural skills, leadership and responsibility, productivity, accountability, media literacy, and ICT. According to Karip (2016), societies that fail to qualify these skills to the young population may risk becoming victims of the Industrial Revolution 4.0. In this sense, educational institutions should teach these skills, and in this regard, universities have important roles and responsibilities. However, it is a matter of discussion whether universities qualify these skills or not and what policies they should transform in this process. Therefore, according to faculty members' views, this study purposed to determine what kind of policy transformation universities need to catch the 4.0 industrial revolution regarding education-instruction, technical infrastructure, and administrative structures. In this regard, some results were obtained.

According to a result obtained through this study, participant faculty members generally consider that universities need major policy shifts in order to train human resources needed by the Industrial Revolution 4.0 in Turkey. In this context, they think that existing administrative structures and policies are rather reactive. However, proactive policies and decisions are needed for the Industrial Revolution 4.0. In this regard, Yazıcı and Düzkaya (2016) argue that universities cannot qualify human resources compatible with the needs of the Industrial Revolution 4.0 workforce. For this reason, they should renew their courses and course contents, open multi-disciplined programs, especially in genetics, alternative energy, and empower informatics, innovation, and encourage entrepreneurship. Benešová and Tupa (2017) also discuss that the field of information science for the Industrial Revolution 4.0 in higher education should be addressed with great importance. In this sense, employees' qualifications and skills should be better than the current situation.

Another result reveals that libraries' physical capacity is insufficient at universities according to the number of students. In this manner, the physical environment of libraries are small, books, electronic database, internet access, visual and audio resources, periodical newspapers, magazines, CD media resources, and publications are limited. Libraries should 
be basic learning centers at universities. They should be improved to meet basic learning needs.

According to another result reached in the research, the classroom is the most important place where students learn. The participants of this sample emphasized that interactive boards and internet access are important in increasing learning efficiency. Also, the seating design of a classroom is a crucial element in learning. They should enable interaction among student-student and student-teacher. However, it was understood that in most classrooms of this sample, there is a column style seating arrangement that negatively affects interaction and teamwork. This seating arrangement also limits socialization, knowledge sharing, and informal learning. Hence, Chea and Huan (2019) noted in their study that the university system should change according to the needs of the young generation, both physically and academically. They added that as most available information should be outdated by 2050, universities should be flexible and ready to anticipate the future for education 4.0. Similarly, Jamaludin, McKay, and Ledger (2019) put that some changes should be made in education policies at universities, and programs should be renewed according to the needs of the Industrial Revolution 4.0. In this regard, some contemporary programs such as simulation and augmented reality, horizontal and vertical integration, ICT, cyber security, cloud computing, mass production, artificial intelligence, supply chain, big data analysis, and autonomous robots should be added to the programs.

According to another result, the laboratory infrastructure of universities is insufficient. In this manner, the participants claim that the capacity of laboratories is limited, technology is old, and some devices are broken. Moreover, correct measurements cannot be made due to calibration problems. They also added that they could not buy materials and equipment for the laboratories due to financial constraints. There are serious financial constraints on universities, and this affects facilities carried out at universities directly. This may lead to problems with educating and training professionals expected for the Industrial Revolution 4.0. Hence, Mahmud and Ridgman (2019) more specifically demonstrated that preparing graduates as good professionals is quite important in the Industrial Revolution 4.0. Here, universities should prepare their graduates according to the needs of the Industrial Revolution 4.0.

A further result showed that the curriculum is generally intensive, and classes are conducted theory-based. In this atmosphere, the classes are often teacher-centered, and student participation is not allowed. In this regard, they underlined that encyclopedic 
knowledge is transferred to students in the classes, and there is not much room for practice. On the other hand, they observed that courses were conducted based on practice during their visits abroad. In this sense, Baygin, Yetis, Karakose, and Akın (2016) and Raman and Rathakrishnan (2019) noted that universities should prepare professionals to achieve rapid transformation with the Industrial Revolution 4.0 based on practice.

A final result showed that university administrators are appointed without considering their administrative competence and experience. Rather, they are chosen with political considerations. In this context, it was claimed that the criteria for appointment rectors and other mid-administrators are not clearly defined in the higher education management system. This may lead to the intervention of politicians to academic life easier. In addition, since the faculty vote right was canceled, rectors became insensitive to politicians' demands. This situation may lead to organizational silence among faculty members. Hence, Çankaya and Töremen (2010) reported that academicians' participation in voting could make academic life more peaceful.

\section{Conclusions}

In conclusion, in order to embrace the Industrial Revolution 4.0, universities should strengthen the social, cultural, and intellectual capital of human resources, improve adaptability, increase competencies, improve digital literacy capacity, make employees media literate, enable transdisciplinary work, design thinking and be ready for virtual cooperation in administrative structures. Therefore, it is imperative to empower publicprivate community participation and develop a new mindset, skill sets, and technology for lecturers and students. The recommendations reached through this study are below:

- Universities' technological infrastructure should be improved.

- The academic database should be accessible for all students at every university for free.

- Libraries should be designed to meet the learning and resource demands of students.

- Classrooms should be designed appropriately for student-centered and group work studies.

- Courses should be conducted practice-based instead of theory-based.

- 3D technologies should be expanded at universities. 
K. Özcan, A. Balyer / Pamukkale University Journal of Education, 53, 261-279, 2021

- Lecturers should be trained on teaching methods and strategies.

- Student clubs and organizations should be strengthened and funded to increase cultural, artistic, sports, and scientific activities.

- University administrators should be asked administrative experience and competencies while appointing.

- Democratic and participative mechanisms should be put into practice.

Ethical Approval: Since the data of this study were collected in 2019, the ethics committee's approval was not obtained.

Conflict Interest: The authors declare no conflict of interest.

Authors Contributions: The authors have contributed equally to this paper.

\section{References}

Balc1, A. (2015). Sosyal bilimlerde araştırma. Ankara: Pegem.

Baygin, M., Yetis, H., Karakose, M. \& Akin, E. (2016). An effect analysis of industry 4.0 to higher education," 2016 15th International Conference on Information Technology Based Higher Education and Training (ITHET), Istanbul, 2016, pp. 1-4.

Benešová, A., \& Tupa, J. (2017). Requirements for education and qualification of people in industry 4.0. 27th International Conference on Flexible Automation and Intelligent Manufacturing, Procedia Manufacturing, 11 (2017), 2195- 2202, doi: 10.1016/j.promfg.2017.07.366

Büyüköztürk, Ş., Kılıç, Ç. E., Akgün, Ö. E., Karadeniz, Ş. \& Demirel, F. (2008). Bilimsel araştırma yöntemleri (2.Basım). Ankara: Pegem Akademi.

Carl, J. (2009). Industrialization and public education: social cohesion and social stratification. In: Cowen R., Kazamias A.M. (eds) International Handbook of Comparative Education. Springer International Handbooks of Education, 22. Springer, Dordrecht. DOI: https://doi.org/10.1007/978-1-4020-6403-6_32

Chea, C. C. \& Huan, J. T. J. (2019). Higher education 4.0: the possibilities and challenges. Journal of Social Sciences and Humanities, 5(2), 81-85.

Creswell, J.W. (2007). Qualitative inquiry and research design: Choosing among five approaches. Thousand Oaks: Sage. 
Denzin, N. K. \& Lincoln, Y.S. (2005). The sage handbook of qualitative research, 3rd Edition, Thousand Oaks, CA: Sage.

Glaser, B. G. (1992). Basics of grounded theory analysis. Mill Valley, Ca.: Sociology Press.

Grubb, W. \& Lazerson, M. (2004). The education gospel: The economic power of schooling. Cambridge, MA: Harvard University Press

Jamaludin, R., McKay, E., \& Ledger, S. (2019). Are we ready for education 4.0 within ASEAN higher education institutions? Thriving for knowledge, industry and humanity in a dynamic higher education ecosystem? Journal of Applied Research in Higher Education, 12(3), 1-13. doi.org/10.1108/JARHE-06-2019-0144

Karasar, N. (2007). Araştırmalarda rapor hazırlama (14.baskı). Ankara: Nobel Yayıncılık.

Karip, E. (2016). Dördüncü sanayi devrimi ve eğitim, TEDMEM. https://tedmem.org/vurus/dorduncu-sanayi-devrimi-egitim, Erişim: 23.03.2020.

Katz, M. (1987). Reconstructing American education. Cambridge, MA: Harvard University Press.

Kümbetoğlu, B. (2005). Sosyolojide ve antropolojide niteliksel yöntem ve araştırma. İstanbul: Bağlam.

Mahmud, N., \& Ridgman, T. W. (2019). Interdisciplinary higher education: redesigning for industry 4.0. IGI Global, 2019. 1-22. Web. 19 Apr. 2020. doi:10.4018/978-1-52257832-1.ch001

Marshall, C., \& Rossman, G.B. (2006). Designing qualitative research (4 th ed.). Thousand Oaks, CA: Sage.

Mayring, P. (2000). Qualitative content analysis. Forum: Online Journal Qualitative Social Research, 1(2), 1-10.

McMillan, J. H. (2000). Educational research fundamentals for the consumer (3. edition). New York: Longman.

Miles, M. B. \& Huberman, M.A. (1994). Qualitative data analysis: A Sourcebook of New Methods. Beverly Hills: Sage.

Önday, Ö. (2017). Dijital dönüşüm. Ankara: Gazi Publications. 
K. Özcan, A. Balyer / Pamukkale University Journal of Education, 53, 261-279, 2021

Penprase, B. E. (2018). The fourth industrial revolution and higher education. In: Gleason N.(eds) Higher Education in the Era of the Fourth Industrial Revolution. Palgrave Macmillan, Singapore.

Punch, K. F. (2005). Introduction to social research-quantitative \& qualitative approaches. London: Sage.

Raman, A., \& Rathakrishnan, M. (2019). Redesigning higher education initiatives for ındustry 4.0. Hershey PA, USA: IGI Global

TEDMEM (2018) Bir bakışta eğitim. https://tedmem.org/mem-notlari/degerlendirme/birbakista-egitim-2018 Erişim: 01.10.2020.

Toffler, A. (2008). Üçüncü dalga (Çev. Selim Yeniçeri). 1. Baskı, İstanbul: Koridor Yayınc1lık.

TÜSİAD (2016). Turkey's global competitiveness as a requirement for industry 4.0: Emerging economy perspective. Retrieved on March 20, 2018 from http://www.tusiad.org/indir/2016/sanayi-40.pdf

Yazıc1, E., \& Düzkaya, H. (2016). Endüstri devriminde dördüncü dalga ve eğitim: Türkiye dördüncü dalga endüstri devrimine hazır mı? Eğitim ve Insani Bilimler Dergisi: Teori ve Uygulama, 7(13), 49-88

Yıldırım, A. \& Şimşek, H. (2011). Sosyal bilimlerde nitel araştırma yöntemleri. Ankara: Seçkin Yayıncılık. 


\subsection{Sanayi Devrimi Bağlamında Yükseköğretim Politikalarının Dönüşümü*}

\section{Kenan ÖZCAN*Aydın BALYER ${ }^{* *}$}

- Geliş Tarihi: 05.05.2020 • Kabul Tarihi: 26.03.2021 • Çevrimiçi Yayın Tarihi: 12.04.2021

\section{$\ddot{\mathbf{O} z}$}

$\mathrm{Bu}$ çalışma, üniversitelerin 4.0 sanayi devrimine uyum sağlama sürecinde eğitim-öğretim, teknik altyap1 ve uygulama ile yönetim süreçlerinde nasıl bir politika dönüşümüne gereksinim duyduğunu belirmeyi amaçlamaktadır. Çalışmada nitel araştırma desenlerinden "durum çalışması" yaklaşımı kullanılmıştır. Araştırma verileri yarı yapılandırılmış görüşme yöntemiyle toplanmıştır. Sekiz üniversiteden 15 farklı branşta, dört kadın ve on bir erkek öğretim üyesinden oluşan katılımcılar, amaçlı örnekleme yöntemine göre belirlenmiş olup tamamı yurt dışında bir üniversitede lisansüstü eğitim yapmış ya da bir projeye katılmıştır. Araştırma verileri içerik analizi türlerinden tümevarımcı analiz yöntemi ile çözümlenmiştir. Araştırma sonuçları Türkiye'deki üniversitelerin dördüncü sanayi devriminin ihtiyaç duyduğu insan kaynağını yetiştirebilmesi için önemli politika dönüşümlerine gereksinimin duyduğunu göstermiştir. Bu sonuca ek olarak mevcut yapılar ve politikaların daha çok reaktif olduğu ve endüstri 4.0 için proaktif yapılara ihtiyaç olduğu sonucuna ulaşılmıştır. Üniversitelerdeki kütüphane, derslik, laboratuvarların fiziksel kapasitesinin öğrenci sayısına göre yetersiz, dijital bilgi kaynaklarına erişimin sınırlı olduğu anlaşılmıştır. Öğretim programının genelde teorik ve ders içeriklerinin yoğun olduğu, derslerin genelde ansiklopedik bilgi aktarımı şeklinde yürütüldüğü sonucuna ulaşılmıştır.

Anahtar Kelimeler: 4.0 sanayi devrimi, 21. yüzyıl becerileri, yükseköğretim, eğitim politikaları.

Atıf:

Özcan, K. ve Balyer, A. (2021). 4.0 Sanayi devrimi bağlamında yükseköğretim politikalarının dönüşümü. Pamukkale Üniversitesi Eğitim Fakültesi Dergisi, 53, 261-279.doi: 10.9779/pauefd.732724.

\footnotetext{
* Bu araştırmanın bir kısmı 19-22 Haziran 2019 tarihlerinde Ankara Üniversitesinde düzenlenen VI.Uluslararası Avrasya Eğitim Araştırmaları Kongresi'nde sunulmuştur.

* Prof. Dr. Adiyaman Üniversitesi, ORCID: 0000-0002-2106-0972, kozcan04@hotmail.com

** Doç. Dr. Yıldız Teknik Üniversitesi, ORCID: 0000-0003-1784-2522, balyer@yildiz.edu.tr
} 


\section{Giriş}

Dördüncü sanayi devrimiyle bilginin, dijital ve otonom teknolojilere dönüştürülmesi yeni bir toplumsal ilişki biçimini de ortaya çıkarmaktadır. Bu süreç içerisinde standartlaşma, senkronizasyon, merkezi yönetim birimleri, enerji, para ve gücün belli bir kesimin elinde toplandığı üretim ilişkileri yeniden tartışılmaktadır (Toffler, 2008). Bilgi toplumu olarak da adlandırılan ve sınırlarının yeni yeni çizilmeye başladığı söz konusu toplum yapısı içerisinde üretim sektörü giderek akıllı makinelere terk edilmekte ve hizmetler sektörü toplumsal yaşamın merkezine oturmaktadır. Yazıcı ve Düzkaya'ya göre (2016) bu dönemin belirleyicisi, erişimi önceki dönemlere göre daha kolay, ucuz ve zengin olan bilgi birikiminden, üretilen yeni bilgi ve yöntemlerin teknolojiye dönüştürülmesidir. Ancak mevcut bilgiden, yeni bilgi ve yöntemlerin geliştirilmesi için nasıl bir eğitim felsefesinin benimseneceği ve bu yeni bilginin uygulamaya nasıl dönüştürüleceğine ilişkin kesin bir reçete bulunmamaktadır. Buna karşın eğitim ortamında bilgiye ulaşma ve uygulama ağırlıklı bir yapıya dönüştürülmesi için teknolojik altyapının güçlendirilmesi ve sosyal aktiviteler için ortam oluşturulması, staj ve uygulamalarının artırılması sürece katkı sağlayabilir. Chea ve Huan (2019) göre yükseköğretim sisteminin hem fiziksel yapı itibariyle hem de içerik olarak genç neslin ihtiyaçları göz önünde bulundurularak değişmesi gerektiğini ifade etmektedirler. Onlara göre yükseköğretim kurumları esnek ve Eğitim 4.0 için geleceği öngörmeye hazır olmalıdır. 2050 yılına kadar, mevcut tüm bilgiler eskimiş olacaktır. Jamaludin, McKay ve Ledger (2019) yükseköğretimde endüstri 4.0 reformunun sağlıklı ilerlemesi için eğitim politikalarında değişiklik yapılarak (1) simülasyon ve artırılmış gerçeklik; (2) yatay ve dikey entegrasyon; (3) bilgi iletişim teknolojileri; (4) siber güvenlik (5) bulut bilişim; (6) artan üretim (7) yapay zekâ; (8) tedarik zinciri; (9) büyük veri analizi; (10) otonom robot ve (11) yeni iş modelleri gibi yapı taşı bileşenlerin eklenmesi gerektiğini ortaya koymuşlardır. Bunların gerçekleştirilebilmesi için eğitimde kişi başına yapılan harcamaların artırılmasına gereksinim vardır. Ancak günümüzde neo-liberal politikaların da etkisiyle kamu eğitim harcamalarının gittikçe azalması ve eğitimden faydalanan maliyetini öder anlayışının benimsenmesi, eğitimde yeni finansman modellerinin geliştirilmesine istemi de artırmaktadır.

Toplumların yeni endüstri devrimine uyum sağlama ve küresel rekabet güçlerini sürdürebilmelerinde üniversitelerin öncü roller üstlenmelerine ilişkin beklentiler gittikçe artırmaktadır. Günümüzde üniversitelerin toplumsal kültürü aktarma ve yeni bilgi üretme süreçlerinin yanında, bilgiyi patente ve bunun ekonomiye dönüştürme rolü daha çok önem 
kazanmaktadır. Türkiye'nin dördüncü sanayi devrimine uyum sağlanma sürecinde yükseköğretim kurumlarında hangi çalışmaların yürütüldüğg̈ ve nasıl bir politika dönüşümüne ihtiyaç olduğunun belirlenmesine gereksinim duyulmaktadır.

Eğitimin niteliği ile sanayileşmenin gelişimi birlikte gerçekleşmektedir (Carl, 2009). Sanayileşme sürecinden önce formal okullaşma oranı oldukça düşüktür. Eğitim hizmetinden antik dönemden sanayi devrimine kadar varsıl ailelerin erkek çocukları faydalanabiliyor, eğitimin finansmanı ise aileler tarafından karşılanıyordu. Sanayileşme ile gelen zenginlik ve eğitimin önemine inanılması ve varsıl ailelerin eğitime yaptıkları bağışlar neticesinde okullaşma oranını artırmıştır (Katz, 1987). Herkes için eğitim anlayışının gelişmesi okulun önemini artırarak 20. yüzyılda hem ulusal ekonominin gelişmesine hem de bireylerin statülerinin yükselmesine neden oluşmuştur (Grubb ve Lazerson, 2004). Günümüzde OECD ülkelerinde 3-5 yaş aralığındaki öğrencilerin okullaşma oranı \%86, 25-34 yaş aralığındaki ortaöğretim mezunu ortalama $\% 85$, yüksek öğretimde ise okullaşma oranı, ön lisans düzeyinde $\% 16$, lisans düzeyinde $\% 58$, yüksek lisans düzeyinde $\% 24$ ve doktora düzeyinde \%2,5'tir (TEDMEM, 2018).

Sanayinin dördüncü endüstri devrimine evrilmesi sürecine koşut olarak, günümüzde artık 4.0 eğitim yaklaşımları gündeme gelmiştir. Yükseköğrenim alanı söz konusu olduğunda, bu dönüşüm yükseköğretim kurumlarını öğrencilerini rekabetin yoğun olduğu yeni iş alanlarına hazırlama konusunda yeni stratejiler geliştirmeye zorlamaktadır. Bu kapsamda bilgi çağında özellikle üniversiteler üzerinde farklı sektörlerden gelen 21. yüzyıl becerilerini öğrencilere kazandırma konusunda baskılar artmaktadır (Önday, 2017; Penprase, 2018; TÜSİAD, 2016).

Eğitim 4.0 kapsamında ele alınan 21. yüzyıl becerileri, eleştirel düşünme ve problem çözme, iletişim ve iş birliği, yaratıcılık ve yenilikçilik, inisiyatif kullanma ve kendini yönlendirme, sosyal, kültürler arası beceriler, liderlik ve sorumluluk, üretkenlik ve hesap verebilirlik ve medya, enformasyon ve Bilgi ve İletişim Teknolojileri (BİT) okuryazarlığı gibi temel becerilerdir. Benešová ve Tupa (2017) yükseköğretimde endüstri 4.0 için bilgi bilimi alanının önemle ele alınması gerektiğini ileri sürmektedir. Bu anlamda üniversiteler ya da diğer kurumların yeni teknolojiler ve akıllı medya kullanacakları için çalışanların niteliklerine ve becerilerine yönelik gereksinimlerin mevcut durumdan daha yüksek olabilir. Bunların öğrencilere kazandırılması amacıyla yükseköğretimde çağdaş bir müfredatın geliştirilmesi, öğrenme ve uygulama süreçlerinin yeniden yapılandırılması ve katılımcı bir yönetim ile hesap verilebilir denetim yöntemlerinin 
benimsenmesi beklenmektedir. Yükseköğretim alanı söz konusu olduğunda bu dönüşümün ne kadar gerçekleştirildiği araştırılmaya muhtaç bir konudur.

$\mathrm{Bu}$ çalışma, 4.0 Endüstri devrimine uygun insan kaynağının yetiştirilmesi için üniversitelerde öğrencilerin bilgiye erişimi ve teknoloji kullanımı, öğretim süreçleri, öğrenci etkinlikleri ve yönetim süreçlerinde nasıl bir politika dönüşümüne gereksinim olduğunu belirmeyi amaçlamaktadır. Araştırmanın genel amacına ulaşılması için aşağıdaki sorulara yanıt aranacaktır.

a) Yükseköğretim kurumlarında bilgiye erişim ve teknolojinin kullanımına ilişkin öğretim elemanlarının görüşleri nelerdir?

b) Yükseköğretim kurumlarında gerçekleştirilen öğretim süreçlerine ilişkin öğretim elemanlarının görüşleri nelerdir?

c) Yükseköğretim kurumlarında gerçekleştirilen öğrenci etkinliklerine ilişkin öğretim elemanlarının görüşleri nelerdir?

d) Yükseköğretim kurumlarında yöneticilerin belirlenmesi ve bu yöneticilerin yeterliliklerine ilişkin öğretim elemanlarının görüşleri nelerdir?

\section{Yöntem}

Araştırmada nitel araştırma yöntemi kullanılmıştır. Nitel araştırma, gözlem, görüşme ve doküman analizi gibi nitel veri toplama yöntemlerinin kullanıldığı, algıların ve olayların doğal ortamda gerçekçi ve bütüncül bir biçimde ortaya konmasına yönelik nitel bir sürecin izlendiği araştırma olarak tanımlanabilir (Creswell, 2007; Yıldırım ve Şimşek, 2011). Çalışmada nitel bir araştırma deseni olan "durum çalışması” yaklaşımı kullanılmıştır. Durum çalışması, bir veya daha fazla olayın, ortamın, programın, sosyal grubun ya da diğer birbirine bağlı sistemlerin derinlemesine araştırıldığı ve irdelendiği bir yöntemdir (Denzin ve Lincoln, 2005; Marshall ve Rossman, 2006; McMillan, 2000, 45). Yıldırım ve Şimşek (2011) durum çalışmasını, bir veya birkaç durumun derinlemesine araştırılması ve duruma ilişkin verilerin bütüncül bir yaklaşımla analiz edilmesi olarak tanımlamaktadırlar.

\section{Çalışma Grubu}

Araştırmanın çalışma grubunu, 2019-2020 eğitim-öğretim y1lı güz döneminde İstanbul, Yıldız, Adıyaman, Mehmet Akif Ersoy, Pamukkale, Muş Alpaslan, Medeniyet ve Gazi Üniversitelerinin farklı birimlerinde (Eğitim, Fen Edebiyat, Mühendislik Fakültesi) görev yapan ve amaçlı örnekleme yöntemine göre belirlenen 15 akademisyen oluşturmaktadır. Araştırmaya katılan öğretim üyelerinin 4'ü kadın, 11'i erkektir. Katılımcılar 28-52 yaş 
K, Özcan ve A. Balyer/ Pamukkale Üniversitesi Eğitim Fakültesi Dergisi, 53, 261-279, 2021

arasındadır. Her bir öğretim üyesi ile görüşme süresi ortalama 40-55 dk. aralığında olup diğer demografik değişkenler tablo 1'de verilmiştir.

Tablo 1. Katılımcıların Kod İsimleri Branşları Akademik Unvanları ile Yurtdışında Kalma Süresi ve Bulundukları Ülke Dağllımı $(N=15)$

\begin{tabular}{llllc}
\hline $\begin{array}{l}\text { Katılımcı Kod } \\
\text { İsimleri }\end{array}$ & Branş & Unvan & $\begin{array}{l}\text { Yurtdışında } \\
\text { Bulunma Nedeni }\end{array}$ & $\begin{array}{l}\text { Bulundukları } \\
\text { Ülke }\end{array}$ \\
\hline Metin & Bilgisayar Müh. & Dr. Ar. Gör. & Doktora & ABD \\
Osman & Fen Bilgisi & Dr. Öğr. Üyesi & Dok. Sonrası Arş. & ABD \\
Elif & Fizik & Prof. Dr. & Dok. Sonrası Arş. & İsviçre \\
Umut & Psik. Dan. ve Reh. & Dr. Öğr. Üyesi & Doktora & ABD \\
Ebru & Felsefe & Dr. Öğr. Üyesi & Doktora & ABD \\
Selçuk & Özel Eğitim & Dr. Öğr. Üyesi & Doktora & ABD \\
Arda & Endüstri Müh. & Doç. Dr. & Dok. Sonrası Arş. & ABD \\
Muhammed & İnşaat Müh. & Doç. Dr. & Doktora & ABD \\
Şenay & Eğitim Yönetimi & Doç. Dr. & Doktora & ABD \\
Ozan & Matematik & Dr. Ar. Gör. & Doktora & ABD \\
Gülsen & Biyoloji & Dr. Öğr. Üyesi & Dok. Sonrası Arş. & ABD \\
Ahmet & Kimya & Doç. Dr. & Doktora & ABD \\
Cemal & Ölçeme ve Değg. & Dr. Öğr. Üyesi & Doktora & ABD \\
Ardıl & Makine Müh. & Prof. Dr. & Dok. Sonrası Arş. & ABD \\
\hline ABD Amesi & Doktora & \\
\hline
\end{tabular}

$\mathrm{ABD}=$ Amerika Birleşik Devletleri

Tablo 1 incelendiğinde, araştırmaya katılan öğretim elemanlarının 14 farklı branşta görev yaptıkları görülmektedir. Katılımcıların 2’si Dr. Ar.Gör., 7 ‘si Dr. Öğr. Üyesi, 4’ü Doç. Dr. ve 2'si ise Prof. Dr. olarak görev yapmaktadır. Öğretim elemanlarından 5'i doktora sonrası araştırmacı olarak, 10'u ise doktorasını yapmak amacıyla yurt dışında bulunmuştur. Katılımcılardan 1'i İsviçre'de 14'ü ise ABD'de bulunmuş olup yurt dışında kalma süresi 1-8 y1l arasindadir.

\section{Veri Toplama Aracı}

Araştırma verileri yarı yapılandırılmış görüşme formu yöntemine göre toplanmıştır. Karasar'ın (2007) belirttiği üzere “bu yöntem ne tam yapılandırılmış görüşmeler kadar katı ne de yapılandırılmamış görüşmeler kadar esnektir”. Araştırmacıya bu esnekliği sağladığı 
için bu yöntem kullanılmıştır. Yarı yapılandırılmış görüşmede amaç bireylerin verdikleri bilgiler arasındaki paralelliği ve farklılığı saptamak ve buna göre karşılaştırmalar yapmaktır (Balc1, 2015; Büyüköztürk, Kılıç Çakmak, Akgün, Karadeniz ve Demirel, 2008, 151; Kümbetoğlu, 2005; Punch, 2005). Araştırmanın verilerini toplamak amaciyla görüşme formu hazırlanmıştır. Formun geliştirilmesi sürecinde konuya ilişkin literatür taranmış ve sorular oluşturulmuştur. Araştırmacılar dışında üç alan uzmanının görüşleri doğrultusunda forma son şekli verilmiştir.

\section{Verilerin Analizi}

Araştırma verilerinin çözümlenmesinde içerik analizi türlerinden tümevarımcı analiz yöntemi kullanılmıştır. $\mathrm{Bu}$ tür analizler genellikle bir konu üzerinde toplanan benzer verilerin bir araya getirilmesi, analiz edilmesi ve yorumlanmasında kullanılır (Büyüköztürk ve diğ. 2008; Mayring, 2000; Yıldırım ve Şimşek, 2011). Tümevarımcı analiz, kodlama yoluyla verilerin altında yatan kavramları ve bunların arasındaki ilişkileri ortaya çıkarmak amacıyla yapılmaktadır (Miles ve Huberman, 1994; Yıldırım ve Şimşek 2011). Bu araştırma verilerinin analizi üç aşamada gerçekleştirilmiştir. Birinci aşamada ses kaydı olarak elde edilmiş veriler yazılı olarak elde edilen verilerle karşılaştırılmıştır. İkinci aşamada araştırmacı ile nitel araştırma konusunda deneyimli bir başka öğretim üyesi ayrı ayrı yazılı verileri kodlamışlardır. Güvenirlik için her iki araştırmacı tarafından yapılan kod-lamalar üzerinde Güvenirlik= Görüş Birliği/ Görüş Birliği + Görüş Ayrllĭgl X 100 formülü uygulanmıştır (Miles ve Huberman, 1994). İki kodlayıcı arasında uyuşum yüzdesi \%90 olarak hesaplanmıştır. Uyuşum yüzdesinin $\% 70$ ya da daha üstü olması yeterli görüldüğünden veri analizi açısından güvenirlik sağlanmıştır. Araştırmacı ve uzman öğretim üyesi tarafından yapılan kodlamalarda uyuşum gösteren kodlar temalara ulaşmada temele alınmıştır.

\section{Bulgular}

Çalışmanın bulgular başlığında, araştırmanın alt amaçları doğrultusunda ulaşılan veriler sistematik bir biçimde sunulmuştur. Bu doğrultuda öğretim üyelerinin üniversitelerindeki, bilgiye erişim ve teknoloji kullanımı, öğretme-öğrenme süreçleri, öğrenci etkinlikleri ile üniversitenin yönetimi ve denetimi konularında mevcut duruma ilişkin görüşleri analiz edilerek yorumlanmıştır. Katılımcıların üniversitede bilgiye erişim ve teknoloji kullanımına ilişkin görüşleri tablo- 2’ de verilmiştir. 
Tablo 2. Öğretim Üyelerinin Görev Yaptıkları Üniversitelerde Bilgiye Erişim ve Teknolojinin Kullanımına İlişkin Görüşleri $(N=15)$

\begin{tabular}{|c|c|c|}
\hline Tema & Alt Temalar & Kodlar \\
\hline \multirow{22}{*}{ 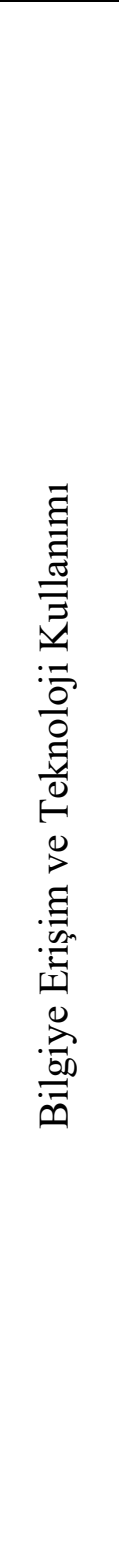 } & \multirow{9}{*}{ Kütüphane } & Yetersiz kapasite \\
\hline & & Kitap sayısı az \\
\hline & & Ortam çeşitliliği sınırlı \\
\hline & & Veri tabanına erişim sınırlı \\
\hline & & Film ve belgesel yok \\
\hline & & Wi-Fİ zayıf \\
\hline & & Sadece mesaide açık \\
\hline & & Günlük gazeteler yok \\
\hline & & Süreli dergiler sınırlı \\
\hline & \multirow{6}{*}{ Sinıf Donanımı } & Sıralı sütuün oturma düzeni \\
\hline & & Ergonomik sorunlar \\
\hline & & Etkileşimli tahta \\
\hline & & Projeksiyon \\
\hline & & Bilgisayar \\
\hline & & İnternet \\
\hline & \multirow{7}{*}{ Laboratuvar Altyapısı } & Sınırlı etkinlik \\
\hline & & Eski teknoloji \\
\hline & & Cihazlar arızalı \\
\hline & & Sinırlı kullanım \\
\hline & & Gereç yetersiz \\
\hline & & Kapasite yetersiz \\
\hline & & Kalibrasyon sorunu \\
\hline
\end{tabular}

Tablo 2'de görüldügü üzere, katılımcıların üniversitede bilgiye erişim ve teknoloji kullanımına ilişkin görüşleri kütüphane, sınıf ve laboratuvar alt tema ve kodlara göre analiz edilmiştir. Katılımcılar üniversitede bilgiye erişim için teknolojik altyapı konusunda birinci alt tema olan kütüphanenin merkezi bir konuma sahip olduğunu belirtmelerdir. Buna karşın, üniversitelerdeki kütüphanenin fiziksel kapasitesinin öğrenci sayısına göre yetersiz, çalışma ortamı çeşitliliğinin (tek, grup, takım çalışmasına uygun ve sessiz, elektronik bilgiye erişim ve konfor özellikleri vs) sınırlı, kitap sayısı ve yayın çeşitliliği ile kütüphanenin günlük 
hizmet verme süresinin çoğu zaman mesai ile sınırlandırıldığını vurgulanmıştır. Ayrıca kütüphanede elektronik veri tabanına erişimin finansman sorunu nedeniyle sınırlı, öğrencilerin bilgiye erişimleri için bilgisayar sayısının yetersiz ve kablosuz internetin (WiFi’) güçlü olmadığını, süreli gazete, çeşitli dergi ve CD ortamında görsel ve işitsel (film ve belgesel vb) kaynaklarının oldukça sınırlı olduğunu belirtmişlerdir. "Yaklaşık 15 yıllık geçmişine karşın üniversitemizde kütüphane binası yok ögrencilerimizin kitapları ödünç alıp verdiği bir birim var (Metin). "Yurt dışında bulunduğum üniversitenin kütüphanemizde bir milyon daha fazla kitap vard, erişim günün 24 saatinde, ulusal ve dini bayramlar hariç her zaman açıktı (Şenay). Aslında günümüzde kütüphane olgusunun da değiştiği söylenebilir. Bilgi tabanın değişmesi, kaynakların elektronik ortama aktarılması kolay ve ucuz erişimi olanağını sağlamaktadır. "Öğrencilerimizin ülkedeki basılı ve elektronik her türlü kaynağa kolay erişebilmesi için kütüphanelerin entegre olması gerekir” (Osman). Günümüzde kütüphaneler basılı kaynakların yanı sıra zengin bir veri tabanına kolay erişilebilen, fiziksel kapasitesi yüksek, öğrencilerin tek, grup veya takım olarak çalışmasına olanak sağlayacak biçimde tasarlanmaktadır. Ayrıca kütüphanelerin öğrencilerin temel gereksinimlerini karşılayabilecek kapasitede ve konforda, pek çok etkinliğin yapılabildiği çok katlı bir öğrenme merkezi şeklinde tasarlanması gerekmektedir.

Katılımcılar, öğrencilerin meslek alanlarına ilişkin kuramsal boyutta öğrenmenin gerçekleştiği en önemli yerin sınıf olduğunu belirtmişlerdir. Sınıfın oturma düzeni, ergonomik koşulları ile sınıfta bilginin paylaşımı sürecindeki etkililiği artırmada etkileşimli tahta, bilgisayar ve projeksiyon makinesinin bulunmasının ve internet erişiminin önemli olduğunu belirtmişlerdir. Buna karşın katılımcılar uygulamada sınıftaki teknolojinin etkin bir biçimde kullanılmadığını belirtmişlerdir. "Etkileşimli tahtada öğretim sürecine destekleyen programlar yüklü değil, sadece projeksiyon makinesi gibi kullanıyoruz, neden projeksiyon makinesinin sınıftan kaldırılıp çok pahalı olan etkileşimli tahta konduğunu anlamak mümkün değil (Osman)" "Sinıfta internet erişimi olmasına karşın, şifre sorunu nedeniyle derslerde kullanamıyorum" (Elif). Etkileşimli tahtada pek çok uygulama yapılıyor olmasına karşın, bize bu konuda eğitim verilmediği için sinırlı düzeyde kullanılamamaktadır (Umut) Öğretim üyeleri, üniversitelerimizde sınıf düzenin öğrencilerin sıralı ve arka arkaya dizildikleri bir biçimde oturduklarını belirterek, bunun öğrenciler arasında takım çalışmasını olumsuz etkilediğini, bilgi paylaşımını ve informal öğrenmeyi sınırlandırdığını belirtmişlerdir. ABD’de doktorasını tamamlamış olan bir öğretim üyesi sınıf düzeninin önemi dikkat çekerek "SInıflarda bireysel oturma düzeni var, işbirlikçi öğrenme esastır 
(Ozan). Ülkemizde temel eğitimden üniversiteye kadar öğretim kurumlarının tamamında öğrenciler sıralı sütün düzenine göre oturması öğrenciler arasında bilgi paylaşımını ve informal öğrenmeyi sınırlandırdığı söylenebilir. "... üniversitemizde, herkes için eğitim kavramının benimsendiği Birinci Sanayi Devrimiyle oluşturulan sıralı sütün oturma sınıf düzeni, seri ve fason üretim modeline benzer doldur boşalt mantı̆̆ıyla dersler yapılmaktadır " (Ebru). Bu tasarımdaki sınıflar ancak öğretmen merkezli öğretim için kullanılabilir, buna karşın gelişmiş ülkelerde sınıf oturma düzenin daha çok öğrenci merkezli öğretim yöntemine uygun oturma düzeni tasarlanmaktadır. Günümüzde sınıfta düşüncesini ifade eden, iletişim becerisi yüksek, özgür, yaratıcı, eleştirel düşünen, takım halinde çalışarak bir sinerjinin oluşturulduğu sınıf tasarımına gereksinim vardır.

Katılımcılar, kuramsal bilginin uygulanması ve evrensel geçerliliği olan bir ürüne dönüştürülmesi süreçlerinde üniversitelerin laboratuvar altyapısının güçlü olması ve kullanılmasının önemini vurgulamışlardır. Bu konuda "Öğrencilerimiz artık bir şey yapmak istiyor, dinlemekten yoruldular" (Turgay) şeklinde görüş bildirerek, "bilen değil yapabilen" profesyonel meslek elemanlarının yetiştirilmesi vurgulanmaktadır. Katılımcılar öğrenci sayısına göre laboratuvar kapasitesinin sınırlı olduğunu, teknolojinin eski, bazı cihazların arızalı ve kalibrasyon sorunu nedeniyle doğru ölçümlerin yapılamadığını, finansman sorunu nedeniyle yeterince sarf malzeme alınamadığını belirtmişlerdir. Bunun yanında mevcut laboratuvardaki bazı makinelerin planlama ve teknik personel sorunu nedeniyle kullanılamamaktadır. “Atölyeye 80.000 TL'ye CNC alındl, ancak kullanacak personel yok"(Ardil). Fakülte yöneticileriyle defalarca konuşmama ră̆men, fakültemizdeki 40 bilgisayardan oluşan laboratuvar, ders saatleri dışında öğrencilerin erişimine açılmadı" (Muhammed). Bölümüzde mail sistemini ve etkileşimli tahtayı etkili kullanmayan öğretim elemanları var (Ahmet). Diğer taraftan "Mühendislik fakültesi öğrencilerine ödevleri yapıp bana gönderin dedim, nasıl göndereceğini sordular, bende otomasyonda gönderin dedim, böylece ilk kez sistemi kullanmış oldular, ancak bana ödev geldi mi diye soranlar oldu, emin olmak için 3 defa mail gönderenler var. Öğrencilerimizin internet okuryazarlıkları oldukça zaylf bu nedenle kağıtla ödev vermekte ısrar ediyorlar (Metin). Öğrencilere bilgisayar ve dijital okuryazarlık ile robotik kodlama becerinin kazandırılması, bilgiye erişim ve tasarım süreçlerine katkı sağlayabilecektir. 
Tablo 3. Öğretim Üyelerinin Yüksek Öğretim Kurumlarındaki Öğretim Süreçlerine İlişkin Görüşleri $(N=15)$

\begin{tabular}{|c|c|c|}
\hline Tema & Alt Temalar & Kodlar \\
\hline \multirow{16}{*}{ 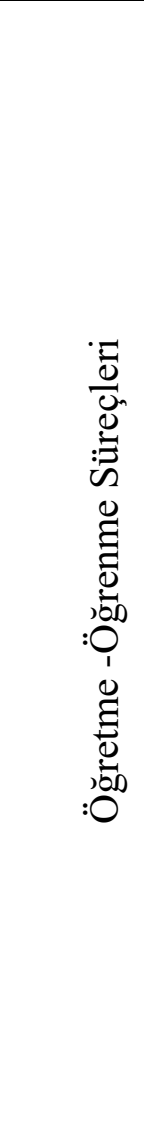 } & \multirow{3}{*}{ Öğretim programı } & Teorik \\
\hline & & Yoğun \\
\hline & & Uygulama sınırlı \\
\hline & \multirow{3}{*}{ Öğretim Yöntemleri ve Uygulaması } & Bilgi kaynağı öğretmen \\
\hline & & Anlatım yönetimi \\
\hline & & Gösteri yöntemi \\
\hline & \multirow{4}{*}{ Uygulama } & Sinırlı uygulama \\
\hline & & Staj süresi yetersiz \\
\hline & & Patent üretimi yetersiz \\
\hline & & Bilginin ekonomik getirisi yok \\
\hline & \multirow{6}{*}{ Öğrenci katılımı } & Genelde pasif \\
\hline & & Hazırlıksız \\
\hline & & Derse katılım sınırlı \\
\hline & & Etkileşim sınırlı \\
\hline & & Takım çalışması yok \\
\hline & & İnformal öğrenme yetersiz \\
\hline
\end{tabular}

Tablo 3'te görüldüğü üzere, katılımcıların üniversitede öğretme-öğrenme sürecine ilişkin görüşleri kütüphane, program, ortam yöntem, uygulama ve öğrenci katılımı alt tema ve kodlara göre analiz edilmiştir. Katılımcılar öğretim programının genelde teorik ve ders içeriklerinin yoğun olduğunu buna karşın uygulamanın sınırlı olduğunu belirtmişlerdir. "On dört haftada ders kitabını bitirmekte zorlanıyorum" (Cemal) şeklinde görüş bildirerek bazı ders içeriklerinin yoğun ve konuların fazla olması nedeniyle sürekli ders anlatmak durumunda kaldığını ve etkinlik yapmaya daha az zaman ayırdığını belirtilmektedir. "Eğitim sosyolojisi haftada iki saat, ancak bu alanda yazılmış en iyi ders kitaplarından biri 46 bölüm ve 500 sayfadan fazla” (Muhammed) şeklinde görüş bildirmiştir. Eğitim fakültelerinde verilen Bilimsel Araştırma Yöntemleri dersinin iki saat yerine, üç saat olması gerektiği vurgulanmaktadır. "Bilimsel araştırma dersini alan öğretmen adayları proje geliştirebilme 
K, Özcan ve A. Balyer/ Pamukkale Üniversitesi Eğitim Fakültesi Dergisi, 53, 261-279, 2021

becerisi kazanmalı, ancak ders saati yetersiz ve sinıflar kalabalık olduğundan araştırma yöntemine ilişkin temel bilgileri verebiliyoruz” (Cemal) şeklinde görüş bildirerek ders içeriğinin yoğun ancak ders saatinin yetersiz olduğu vurgulanmıştır.

Katılımcılar dersin öğretim sürecinde, derslerin genelde bilgi aktarımı şeklinde ve bilgi kaynağının çoğunlukla öğretim üyesi olduğu, öğretim yöntemi olarak ise genelde anlatım ve bunun slaytlarla desteklendiği gösteri yönteminin kullanıldığını belirtmişlerdir. “Üniversitelerimizde derslerde yöntem çeşitliliği çok sınırll, derste daha çok ögretmenler konuşuyor, ögrrenciler dinliyor" (Umut) şeklinde görüş bildirirken "Bilgiye ulaşmak daha kolay ve çok ucuz olduğuna göre aynı bilgileri neden ögrencilere aktarıyoruz? Bilgileri öğrencilerin yorumlayarak yeniden üretebilecekleri şeklinde ögretilmesi için sınıfta yöntem zenginliğine ve ögrenci etkileşimine gereksinim var” (Elif) şeklinde görüş bildirmiştir. Ülkemizde Eğitim Fakülteleri dışında görev yapan bütün birimlerdeki öğretim üyelerinin tamamına yakını Öğretmenlik Meslek Bilgisi derslerini almamışlardır. Dersler öğrencilere, öğretim elemanı tarafından ancak hocalarından öğrendikleri usta çırak yöntemi şeklinde veya kişisel deneyimlerine göre öğretilmektedir. Öğretmen olmak için Öğretmenlik Meslek Derslerinin alınmasının zorunlu olmasına karşın öğretim üyesi olmak için bu konu pek önemsenmemektedir. Ancak gelişmiş ülkelerin üniversitelerinde her bir öğretim yönteminin nasıl kullanılacağı öğretim üyelerine uygulamalı bir biçimde öğretilmektedir. " $A B D$ 'de bulunduğum üniversitede, her alanda doktora yapan öğretim elemanlarına üniversitenin Öğrenme Merkezlerinde, ögrretim yöntem ve teknikleri, sinıf yönetimi, ölçme ve değerlendirme, ders planı hazırlama, istatistik programları vs. uygulamalı olarak verilmekte ve sertifikalandırllmaktadır. Hatta derse giren ögretim elemanlarının dersleri isteğe bağlı olarak kameraya alınıp uzman bir grup tarafindan incelenerek dersin ögretim elemanına dönüt verilmektedir" (Ozan).

Katılımcılar derslerde verilen kuramsal bilginin uygulamaya dönüştürülmesi için birimlerdeki laboratuvar ve drama salonlarının yetersiz olduğunu, işletmelerde staj yapan öğrencilerin uygulama eğitimlerine yeterli önemin verilmediğini, öğrencilerin daha önemsiz ve getir-götür işlerinde çalıştırıldığını, işbaşı eğitim süreçlerinin önemsenmediğini belirtmişlerdir. "Öğretmenlik stajının süresi ve ders saati artırılmall” (Şenay) şeklinde öneri sunarken "Mühendislik öğrencilerinin gerçekten staj yapıp yapmadıklarını sadece dosyaları incelenerek pek anlaşılmıyor" (Arda) şeklinde görüş bildirmiştir. "Mühendislik alanında doktora yapanlardan araştırmaları konusunda bir ürün geliştirmeleri istenir” (Selçuk) şeklinde görüş bildirmişlerdir. Türk eğitim sisteminin en önemli sorunlarından biri verilen 
eğitimin, yaşamdaki karşılığının ne olduğu ve nasıl uygulanacağına ilişkin uygulamaların çok sınırlı kalmasıdır. Günümüzde artık bilmek yeterli değil, yapabilmek, bir ürün ortaya koymak ve yaşamda karşılaşılan bir problemi çözebilmenin daha önemli olduğu bilinmektedir. Bu nedenle öğretim kurumlarında atölye, işlik, laboratuvarın ve drama salonu kurulması eğitim ile yaşam arasında köprü oluşturularak "eğitimin yaşamın kendisidir" anlayışı geliştirilmelidir.

Katılımcılar sınıfta derse katılarak konu hakkında fikir beyan etme, soru sorma ve sorgulama süreçlerine çok az öğrencinin katıldığını belirtmişlerdir. "Her sınıfta en fazla 810 ögrenci derste daha aktif” (Gülsen) şeklinde görüş bildirmiştir. Öğrencilerin sınıfta genelde konuya hazırlıksız geldiklerini ve derste pasif oldukları belirtilmektedirler. Öğrencilerin sıralı sütün düzenine göre oturmaları, onarın sınıfta yalnız ve hatta bazen yabancılaşmalarına neden olabilmektedir. Çünkü öğrencilerin soruları arkadaşlarıyla tartışarak ve bilgi paylaşarak cevap verme ortamı ve kültürü henüz geliştirilememiştir. Öğrencilerin sınıfta yüz yüze bakıp, göz teması kurarak iş birliği içerisinde öğrenme

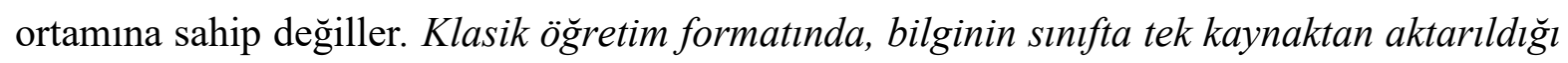
ögretim türü etkili değil ve artık bu tarım toplumunun ögretim yöntemi olduğundan zamanı geçti (Şenay)” Buna karşın iş birliğine dayalı öğretimin gerçekleştirildiği öğretim kurumlarında öğrencilerden yirmi birinci yüzyıl becerilerinden takım halinde çalışma, etkileşim ve iş birliği geliştirerek derse katılmaları beklenir.

Tablo 4'te görüldüğü üzere, katılımcıların yükseköğretim kurumlarında öğrenci etkinlikleri ilişkin görüşleri sosyo-kültürel, spor, sanat ve bilimsel etkinlikler alt tema ve kodlara göre analiz edilerek yorumlanmıştır. Katılımcılar, birimlerinde ve genel olarak üniversitede öğrenci toplulukları etkinliklerinin yetersiz ve katılımının sınırlı olduğunu belirtmişlerdir. "Üniversitede öğrencilerin en az bir topluluğa üye olması, onların sosyalleşmesi ve çevre edinesinde önemli ancak çok az öğrencimiz etkinliklere katılabiliyor" (Ahmet) şeklinde görüş bildirmiştir. Ülkemizde son 15 yılda kurulan üniversitelerin finansman sorunu, kurum kültürü ve geleneklerinin oluşturulamamasından dolayı öğrencilerin sosyo-kültürel etkinlikleri katılımının sınırlı kaldığı söylenebilir. “Öğrencilerimiz, topluluklara katılmaları için pek teşvik edilmiyor (Elif) şeklinde görüş bildirmiştir. Üniversitemizde şiir günleri, felsefe oturumlarının yapılmasını isterdim ancak bu konuda bir anlayış geliştirilemedi" (Umut). "Herhangi bir güvenlik sorunu olmamasına karşın üniversitemiz bahar aylarında kır yürüyüşü bile düzenleyemiyor" (Muhammed) 
şeklinde görüşler bildirilmesine karşın üniversitelerde genelde özel günler ve haftaların kutlandığı ve geleneksel bahar şenliklerinin yapıldığı belirtilmiştir.

Tablo 4. Yüksek Öğretim Kurumlarında Öğrenci Etkinliklerine İlişkin Görüşler (N=15)

\begin{tabular}{|c|c|c|}
\hline Temalar & Alt Tema & Kodlar \\
\hline \multirow{27}{*}{ 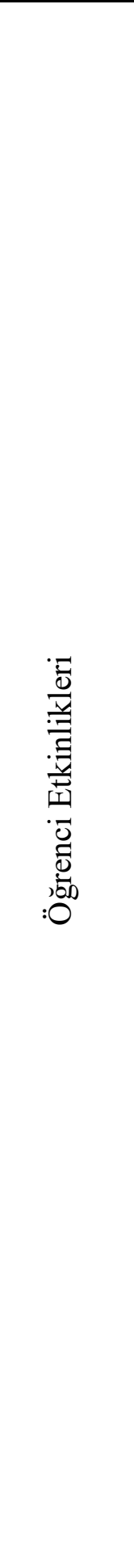 } & \multirow{8}{*}{ Sosyo-kültürel } & Öğrenci toplulukları az \\
\hline & & Öğrenci katılımı sınırlı \\
\hline & & Finansman yetersiz \\
\hline & & Özel günler/haftalar kutlanıyor \\
\hline & & Bahar şenlikleri yapılıyor \\
\hline & & Fikir ve düşünce kulüpleri yok \\
\hline & & Yönetimin desteği sınırlı \\
\hline & & Gizli ve açık sansür var \\
\hline & \multirow{7}{*}{ Spor } & Etkinlik alanı sınırlı \\
\hline & & Lisanlı sporcu öğrenci sayısı az \\
\hline & & Teşvik yok \\
\hline & & Branş çeşitliliği sınırlı \\
\hline & & Antrenör yok \\
\hline & & Finansman yetersiz \\
\hline & & Doğa sporları sınırlı \\
\hline & \multirow{7}{*}{ Sanat } & Müzik grupları oluşmamış \\
\hline & & Stüdyo altyapısı yok \\
\hline & & Amfi tiyatro yetersiz \\
\hline & & Şiir kulübü var \\
\hline & & Tiyatro kulübü etkin değil \\
\hline & & Resim atölyeleri yok \\
\hline & & Eğitimci sayısı sınırlı \\
\hline & \multirow{5}{*}{ Bilimsel etkinlikler } & Sinırlı \\
\hline & & Teşvik yok \\
\hline & & Finansman yok \\
\hline & & Rekabet sinırlı \\
\hline & & Teknik altyapı yetersiz \\
\hline
\end{tabular}


Katılımcılar öğrencilerin spor etkinliklerine katılmaları konusunda da finansman sorunu, öğrencilerin teşvik edilmemesi, yeterli antrenörün bulunmaması, öğrencilerin lise yıllarında ilgilenmemeleri ve spor lisanslarının olmamasından dolayı bu etkinliklere katılımının az olduğu söylenebilir. Ancak her öğrencinin en az bir spor alanıyla ilgilenmesi için teşvik edilmesine gereksinim olduğu belirtilmiştir. "Sorduğumda, sınıfta en fazla 2 veya 3 ögrenci lisanlı sporcu olduğunu söylüyor” (Osman) şeklinde görüş bildirmiştir. Merkez kampüslerindeki spor tesislerinin öğrenci sayısına göre çok az olduğu belirtilmektedir. Kampüste $6 \mathrm{~km}$ mavi bisiklet yolu yapıldı ve ögrencilerimiz kurumun bisikletini kullanarak bu olanaktan faydalanmaktadır (Arda) şeklinde görüş bildirmesine karşın diğer öğretim üyesi yurtdışında "bulunduğum üniversitede ögrenciler masa tenisinden futbola kadar her türlü spor alanlarından ücretsiz faydalanabiliyorlardı" (Şenay) şeklinde görüş bildirmiştir.

Katılımcılar üniversitelerde finansman sorunu nedeniyle kültürel ve sanat altyapısının geliştirilmesinde zorlukların yaşandığını belirtmişlerdir. Müzik, resim, tiyatro ve şiir etkinlikleri için öğrenci topluluklarının oluşturulmasında teknik alt yapı (stüdyo, tiyatro ve öğrenci merkezi vs) donanım kapasitesinin yetersiz ve bu alanda profesyonel eğitimcilerin az olduğunu belirtmişlerdir. Bir öğretim üyesi "...̈̈grencilere bilim kadar, sanatta ögretilmelidir (Turgay)" şeklinde görüş bildirmiştir. Bireylerin yaratıcı düşünme becerilerinin geliştirilmesinde sanat ve kültürel etkinliklerin önemini vurgulamışlardır. Yaratıcı bireylerin yetiştirilmesi için her öğrencinin en az bir sanat alanı ile ilgilenmeleri için olanak sağlanmalıdır.

Katılımcılar üniversitelerde bilimsel etkinliklerin gerçekleştirilmesinin öğrencilerin analitik düşünme becerilerinin geliştirilmesine katkı sağlayacağını belirtmişlerdir. Öğrencilerin çağın ve zamanın ruhuna uygun patent ve ürün geliştirebilmesinin çoklu düşünce becerileriyle mümkün olabileceği vurgulanmıştır. $\mathrm{Bu}$ nedenle üniversitelerde kurumsal bilginin ve hayalin bir ürüne dönüştürülebilmesi için bilimsel etkinliklere önem verilmesi ve teknik altyapının oluşturulması için önlemlerin alınmasının zorunlu olduğu belirtilmiştir. Diğer bir öğretim üyesi "...pozitif bilimin gelişebilmesi için öğrencilere sanat, spor ve edebiyat ile ilgilenecekleri olanaklar sağlanmalıdır (Umut) " şeklinde görüş bildirmiştir. 


\begin{tabular}{|c|c|c|}
\hline Temalar & Alt Tema & Kodlar \\
\hline \multirow{7}{*}{ 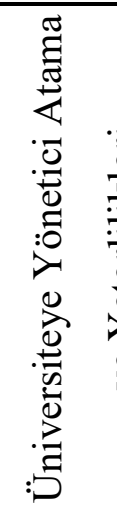 } & \multirow{3}{*}{ Yönetici atama } & Siyasi \\
\hline & & Evrensel ölçüt yok \\
\hline & & Atama kriteri belirsiz \\
\hline & \multirow{4}{*}{ Yöneticilerin Yeterlikleri } & Liderlik vasfı var \\
\hline & & İletişimi güçlü \\
\hline & & Yönetişim kültürü zayıf \\
\hline & & Yönetim kuramı bilgisi sınırlı \\
\hline
\end{tabular}

Tablo 5'te görüldüğü üzere, katılımcıların üniversite yöneticilerinin atanması ve onların yeterliliklerine ilişkin görüşleri tema ve alt temalara göre analiz edilerek yorumlanmıştır. Üniversite yöneticisinin atanmasında evrensel ölçütlerin olmaması ve siyasilerin karar verici konumda olmaları, yöneticilerin yeterlilikleri konusu gerek akademik camiada gerekse kamuoyunda her zaman tartışmalara neden olmaktadır.

Bir öğretim üyesi “...rektörlerin atanmasında açık ve demokratik ilkelerin belirlenmemiş olması siyasetin eğitime ve bilime müdahale etme gerekçesini oluşturmaktadır (Muhammed) şeklinde görüş bildirmiştir. Herhangi bir bilim alanının alt disiplininde uzun y1llar akademik çalışmalar yapan ve öğrenci yetiştiren öğretim üyesinin eğitim yönetimi bilimine ilişkin akademik eğitim veya sertifika programlarına katılmadan kompleks bir yapıdaki üniversiteyi nasıl yöneteceği ve başarılı olma şansı katılımcıların dikkatinden kaçmamıştır. Diğer öğretim üyesi “...rektör adaylarının seçim sürecinde ögretim üyelerinin oy hakkının iptal edilmesi rektörlerin, akademisyenlerin taleplerine duyarsız kalmasına yol açmıştır. Bu durumun üniversitede uygulanacak yeni politikalara öğretim elemanlarının duyarsız kalmasına, motivasyon ve kurumsal adanmışlığın azalmasina hatta zaman zaman kasitlı örgütsel sessizliğe neden olduğunu (Ebru)" belirtmiştir.

Bazı katılımcılar, rektörlerin genellikle otokratik ve sürdürümcü liderlik özellikler gösterdiklerini, girişimci üniversite oluşturma gayreti içinde olduklarını ancak bu konuda alınacak önemli mesafenin bulunduğunu belirtmişlerdir. Ayrıca rektörlerin iletişim becerisi güçlü ve farklı liderlik özelliklerine sahip olmalarına karşın yönetim bilimine ilişkin 
kuramsal ve kavramsal bilgi, katılımcı karar verme ve kurum kültürünün geliştirilmesi konusunda yönetişim süreçlerinin işletilmediğini belirtmişlerdir. Bir öğretim üyesi “....rektörümüz, liyakati esas almak yerine kendi siyasal görüşüne yakın bir ekiple çalışmayı tercih ediyor (Ardı1)..” dedi. Diğer bir öğretim üyesi ise “...rektörlerin doğru politika belirleyebilmesi ve üniversiteyi geleceğe taşıyacak kararlar alabilmesi için katılımcı bir yönetim anlayışını benimsemesi gerekirken üniversiteyi dar bir kadro ile yönetiyor (Muhammed)” şeklinde görüş bildirmiştir.

\section{Tartışma}

Güçlü ve bilimsel eğitim sistemini oluşturan ve herkes için eğitim anlayışını benimseyen ülkeler sanayi devrimlerini gerçekleştirmişlerdir. Eğitim, bundan önce gerçekleştirilen üç sanayi devriminin gelişiminde önemli roller oynamıştır. İçinde bulunduğumuz dördüncü sanayi devrimi toplumun geniş kitlelerine yetkinlikler kazandırmanın ötesinde, 21.yüzyı1 becerileri olarak da isimlendirilen problem çözme, eleştirel ve analitik düşünme, yaratıcılık, liderlik, farklı kültür ve değerlere sahip kişilerle çalışma, duygusal zekâ, yönetişim ve karar verme, hizmet oryantasyonu, bilişsel esneklik gibi becerilere sahip olmalarını zorunlu kılmaktadır. Bu zorunluluk ancak kaliteli bir eğitimin bütün toplum kesimine erişilebilir kı1ınması ile karşılanabilir.

Teknolojinin sunduğu öğrenme platformlarını, yaşam boyu öğrenme ve yeni becerilerin geliştirilmesi amaciyla kullanabilmek yakın gelecekte nüfusun tamamı için zorunlu bir ihtiyaç olacaktır. Karip'e (2016) göre genç nüfusa bu becerileri kazandırmada yetersiz kalan toplumlar dördüncü sanayi devriminin kurbanları konumuna düşme riski ile karşı karşıya kalabilirler. Bu anlamda eğitim kurumları bu becerileri kazandırma konusunda görev almak durumundadırlar ve bu süreçteki en önemli rol ve sorumluluk üniversitelere düşmektedir. Üniversitelerin öğrenme ve uygulama süreçlerindeki teknik altyapıları ve donanımları, öğretme-öğrenme süreçlerinin kalitesi, öğrencilerin bilgi paylaşım ortamlarının çeşitliliği ve üniversitenin yönetim politikaları ülkelerin dördüncü sanayi devrimine geçişini de belirleyebilir.

Endüstri 4.0 devrimine uygun insan kaynağının yetiştirilmesi için, üniversitelerde öğrencilerin bilgiye erişim ve teknoloji kullanımı, öğretim süreçleri, öğrenci etkinlikleri ve yönetim süreçlerinde nasıl bir politika dönüşümüne gereksinim olduğunu belirlemeyi amaçlayan bu çalışmada öğretim üyelerinin konuya ilişkin görüşleri dört alt amaca göre incelenmiş ve ulaşılan bulgulardan hareketle aşağıdaki sonuçlara ulaşılmıştır. 
Genel olarak öğretim üyeleri Türkiye'deki üniversiteleri dördüncü sanayi devriminin ihtiyaç duyduğu insan kaynağını yetiştirebilmesi için önemli politika dönüşümlerine gereksinimin olduğunu düşünmektedirler. Bu kapsamda mevcut yapıların ve politikaların daha çok reaktif olduğu ve endüstri 4.0 için ihtiyaç duyulan proaktif yapılara ihtiyaç olduğunu değerlendirmektedirler.

Yine elde edilen diğer bir sonuca göre katılımcılar üniversitelerdeki kütüphanenin fiziksel kapasitesinin öğrenci sayısına göre yetersiz, çalışma ortam çeşitliliği ile kitap, dergi, günlük gazete sayısı, dijital bilgi kaynaklarına erişim ve kütüphanenin günlük hizmet verme süresinin sınırlı olduğunu düşünmektedirler. Kütüphanelerin öğrencilerin temel gereksinimlerini karşılayabilecek kapasitede ve konforda, pek çok etkinliğin yapılabildiği çok katlı bir öğrenme merkezi şeklinde tasarlanması gerektiği belirtilmiştir.

Araştırmada ulaşılan başka bir sonuca göre öğretim üyeleri öğrencilerin meslek alanlarına ilişkin kuramsal boyutta öğrenmenin gerçekleştiği en önemli yerin sınıf olduğunu değerlendirmektedirler. Sınıfın oturma düzeni, ergonomik koşulları ile sınıfta bilginin paylaşımı sürecindeki etkililiği artırmada etkileşimli tahtanın bulunmasının ve internet erişiminin önemli olduğunu belirtmişlerdir. Ancak ülkemizde temel eğitimden yükseköğretime kadar sınıf düzeninde öğrencilerin sıralı ve arka arkaya dizildikleri bir biçimde oturmalarının, öğrenciler arasında takım çalışmasını olumsuz etkilediğini, sosyalleşmeyi, bilgi paylaşımını ve informal öğrenmeyi sınırlandırdığını belirtmişlerdir. Buna karşı günümüzde sınıfta düşüncesini ifade eden, iletişim becerisi yüksek, özgür, yaratıcı, eleştirel düşünen, takım halinde çalışarak bir sinerjinin oluşturulduğu sınıf tasarımına gereksinimin olduğu vurgulanmıştır.

Başka bir sonuca göre öğretim üyeleri, kuramsal bilginin uygulanması ve evrensel geçerliliği olan bir ürüne dönüştürülmesi için üniversitelerin laboratuvar altyapısının güçlü olması ve kullanılmasının önemini belirtmişlerdir. Öğretim üyeleri, öğrencilerin dinlemekten yorulduğunu, artık yeni ve farklı bir şeyler yapmak istediklerini, bilen değil yapabilen profesyonel meslek elemanları olarak yetiştirilmesi gerektiğini, ancak laboratuvar kapasitelerinin sınırlı olduğunu, teknolojinin eski, bazı cihazların arızalı ve kalibrasyon sorunu nedeniyle doğru ölçümlerin yapılamadığını, finansman sorunu nedeniyle yeterince sarf malzemesi alınamadığını belirtmişlerdir. Bu durum üniversitelerin endüstri 4.0 için beklenen meslek elemanı tipini karşılayamayacağı anlamına gelmektedir. Halbuki, Mahmud ve Ridgman (2019) daha spesifik olarak, endüstri 4.0 için yüksek öğretim bağlamında 
mezunları iyi bir meslek elemanı olarak hazırlamanın bu vizyona uygun disiplinler arası öğretim ve öğrenimin tasarlanmasını ve uygulanmasını gerektirdiğini ortaya koymuşlardır.

Araştırmada elde edilen bir diğer sonuca göre öğretim üyeleri, öğretim programının genelde teorik ve ders içeriklerinin yoğun olduğunu, derslerin genelde ansiklopedik bilgi aktarımı şeklinde yürütüldüğünü belirtmişlerdir. Sınıfta bilgi kaynağının öğrenci katılımından ziyade çoğunlukla öğretim üyesi olduğu, genelde anlatım ve bunun slaytlarla desteklendiği gösteri yönteminin kullanıldığını belirtmişlerdir. Yine katılımcılar öğrenciler arasında bilgi paylaşımı ve derse katılımının sınırlı olduğunu vurgulamışlardır. Öğretim üyelerinin çoğunun öğrenci merkezli ders işleme konusundaki becerilerinin sınırlı olduğunu, hatta çoğu öğretim üyesinin öğretmenlik meslek dersleri almadıklarını ifade etmişlerdir. Buna karşın gelişmiş ülkelerde bulunan ve bu kapsamda görüşülen katılımcı öğretim üyeleri o ülkelerde donanımlı dersliklerin ve çalışma merkezlerinin bulunduğu, dersleri daha çok uygulamaya dönük işlediklerinin altını çizmişledir. Bu anlamda Baygin, Yetis, Karakose ve Akın (2016) endüstri 4.0 ile yaşanan bu hızlı dönüşümü sağlayabilmek için üniversiteler ve diğer yüksek öğretim kurumlarının endüstri 4.0 için ihtiyaç duyulan insan sermayesine sahip olması gerektiğini belirtmişlerdir. Yine Raman ve Rathakrishnan (2019) yükseköğretim kurumlarının rekabetçi kalabilmek için bu dijital dönüşümü bünyelerine katmaları gerektiğini belirtmektedirler.

\section{Sonuç}

Sonuç olarak yükseköğretim kurumları, endüstri 4.0'1 kucaklayabilmek için özellikle insan kaynağının sosyal, kültürel ve entelektüel sermayesini güçlendirmek, uyum yeteneğini geliştirmek, yeterlikleri artırmak, sayısal düşünme becerileri ve dijital okuryazarlık kapasitesini geliştirmek, çalışanları medya okuryazarı yapmak, disiplinler arası çalışmaya olanak sağlamak, tasarım odaklı düşünmeyi teşvik etmek ve yönetsel yapılarda sanal iş birliğine hazır hale getirmek durumundadır. Türkiye'de Endüstri 4.0'ın başarılı bir şekilde uygulanması için öğrenme ağlarının, kamu-özel-toplum katılımının, yeni zihin-seti ve öğretim görevlilerinin ve öğrencilerin beceri setlerinin ve yeni teknolojilerin geliştirilmesi gerektiği değerlendirilmektedir. Üniversitelerimizin dördüncü sanayi devriminin gereksinim duyduğu insan kaynağını yetiştirmesi ve yükseköğretimde politika dönüşümünü gerçekleştirmesi için araştırma sonuçlarına göre aşağıdaki öneriler geliştirilmiştir;

- Her üniversite öğrencisinin bilgiye erişimi için teknolojik alt yapı güncellenmelidir.

- Üniversiteler arası dijital bilgiye erişim olanakları paylaşılmalıdır. 
- Kütüphanelerde tek kişilik veya çoklu gruplar şeklinde çalışma altyapısı sağlanmalıdır,

- Dijital kütüphane oluşturulmalı, veri tabanı genişletilmeli, bunu için üyelik sistemi geliştirilmelidir.

- Klasik anlamda sınıf yerine, öğrenci merkezli ve grup çalışmasının yapıldı̆̆ laboratuvar şeklinde tasarlanmalıdır,

- Öğrencilerin bilgiye kolay ulaşabileceği, etkileşimli sınıf düzeni oluşturulmalı,

- Kuramsal bilgiyi uygulamaya dönüştürebilecek politikalar geliştirilmelidir,

- Öğrencilerin evde hayal edip okulda modelleyip uygulaya bileceği 3D teknolojileri yaygınlaştırılmalı,

- Derslerde öğrenci merkezli ve işbirlikçi öğrenme yöntemlerine ağırlık verilerek öğrenciler arasında informal öğrenme ortamları oluşturulmalıdır.

- Üniversitelerde sosyo-kültürel, sanat spor ve bilimsel etkinliklerinin çeşitliliği artırılması için öğrenci toplulukları kurulmalı,

- Sosyo-kültürel ve bilimsel etkinliklerin çeşitlendirilmesi için yeterli finansman sağlanmalı,

- Her öğrencinin farklı branşlarda spor yapabilmesi için alt yap1 ve kapasite güçlendirilmelidir.

- Üniversite yöneticilerinin atanmasında evrensel ölçütler esas alınmalı, süreç siyasetin etkisinden arındırılmalıdır.

- Üniversite yönetimi diyaloğa açık, demokratik ve eğitim bileşenleriyle birlikte süreci şekillendirecek, yönetişim kültürü geliştirmelidir.

- Her üniversite 4.0 sanayi devrimi bağlamındaki kendi gelişimini izlemek için periyodik araştırmalar yaparak yeni politikalar belirlemelidir.

Etik Kurul İzin Bilgisi: Bu çalışmanın verileri 2019 yılında toplandığından etik kurul izni alınmamıştır.

Yazar Çıkar Çatışması Bilgisi: Yazarların beyan edeceği bir çıkar çatışması yoktur.

Yazar Katkısı: Yazarların makaleye katkısı eşit düzeydedir. 


\section{Kaynakça}

Balc1, A. (2015). Sosyal bilimlerde araştırma. Ankara: Pegem.

Baygin, M., Yetis, H., Karakose, M. ve Akin, E. (2016). An effect analysis of industry 4.0 to higher education," 2016 15th International Conference on Information Technology Based Higher Education and Training (ITHET), Istanbul, 2016, pp. 1-4.

Benešová, A., ve Tupa, J. (2017). Requirements for education and qualification of people in industry 4.0. 27th International Conference on Flexible Automation and Intelligent Manufacturing, Procedia Manufacturing, 11(2017),2195-2202, doi: 10.1016/j.promfg.2017.07.366

Büyüköztürk, Ş., Kılıç, Ç. E., Akgün, Ö. E., Karadeniz, Ş. ve Demirel, F. (2008). Bilimsel araştırma yöntemleri (2.Basım). Ankara: Pegem Akademi.

Carl, J. (2009). Industrialization and public education: social cohesion and social stratification. In: Cowen R., Kazamias A.M. (eds) International Handbook of Comparative Education. Springer International Handbooks of Education, 22. Springer, Dordrecht. DOI: https://doi.org/10.1007/978-1-4020-6403-6_32

Chea, C. C. ve Huan, J. T. J. (2019). Higher education 4.0: the possibilities and challenges. Journal of Social Sciences and Humanities, 5(2), 81-85.

Creswell, J.W. (2007). Qualitative inquiry and research design: Choosing among five approaches. Thousand Oaks: Sage.

Denzin, N.K. \& Lincoln, Y. S. (2005). The sage handbook of qualitative research, 3rd Edition, Thousand Oaks, CA: Sage.

Glaser, B.G. (1992). Basics of grounded theory analysis. Mill Valley, Ca.: Sociology Press.

Grubb, W. \& Lazerson, M. (2004). The education gospel: The economic power of schooling. Cambridge, MA: Harvard University Press

Jamaludin, R., McKay, E., \& Ledger, S. (2019). Are we ready for Education 4.0 within ASEAN higher education institutions? Thriving for knowledge, industry and humanity in a dynamic higher education ecosystem? Journal of Applied Research in Higher Education, 12(3), 1-13. doi.org/10.1108/JARHE-06-2019-0144

Karasar, N. (2007). Araştırmalarda rapor hazırlama (14.baskı). Ankara: Nobel Yayıncılık. 
K, Özcan ve A. Balyer/ Pamukkale Üniversitesi Eğitim Fakültesi Dergisi, 53, 261-279, 2021

Karip, E. (2016). Dördüncü sanayi devrimi ve eğitim, TEDMEM. https://tedmem.org/vurus/dorduncu-sanayi-devrimi-egitim, Erişim: 23.03.2020.

Katz, M. (1987). Reconstructing American education. Cambridge, MA: Harvard University Press.

Kümbetoğlu, B. (2005). Sosyolojide ve antropolojide niteliksel yöntem ve araştırma. İstanbul: Bağlam.

Mahmud, N., ve Ridgman, T. W. (2019). Interdisciplinary higher education: redesigning for industry 4.0. IGI Global, 2019. 1-22. Web. 19 Apr. 2020. doi:10.4018/978-1-52257832-1.ch001

Marshall, C., \& Rossman, G.B. (2006). Designing qualitative research (4 th ed.). Thousand Oaks, CA: Sage.

Mayring, P. (2000). Qualitative content analysis. Forum: Online Journal Qualitative Social Research, 1(2), 1-10.

McMillan, J. H. (2000). Educational research fundamentals for the consumer (3. edition). New York: Longman.

Miles, M.B. \& Huberman, M. A. (1994). Qualitative data analysis: A Sourcebook of New Methods. Beverly Hills: Sage.

Önday, Ö. (2017). Dijital Dönüşüm. Ankara: Gazi Publications.

Penprase, B. E. (2018). The fourth industrial revolution and higher education. In: Gleason N.(eds) Higher Education in the Era of the Fourth Industrial Revolution. Palgrave Macmillan, Singapore.

Punch, K.F. (2005). Introduction to social research-quantitative \& qualitative approaches. London: Sage.

Raman, A., \& Rathakrishnan, M. (2019). Redesigning higher education initiatives for ındustry 4.0. Hershey PA, USA: IGI Global

TEDMEM. (2018) Bir bakışta eğitim. https://tedmem.org/mem-notlari/degerlendirme/birbakista-egitim-2018 Erişim: 01.10.2020. 
Toffler, A. (2008). Üçüncü dalga (Çev. Selim Yeniçeri). 1. Baskı, İstanbul: Koridor Yayınc1lık.

TÜSİAD. (2016). Turkey's global competitiveness as a requirement for industry 4.0: Emerging economy perspective. Retrieved on March 20, 2018 from http://www.tusiad.org/indir/2016/sanayi-40.pdf

Yazıc1, E., ve Düzkaya, H. (2016). Endüstri devriminde dördüncü dalga ve eğitim: Türkiye dördüncü dalga endüstri devrimine hazır mı? Ĕgitim ve Insani Bilimler Dergisi: Teori ve Uygulama, 7(13), 49-88.

Yıldırım, A. ve Şimşek, H. (2011). Sosyal bilimlerde nitel araştırma yöntemleri. Ankara: Seçkin Yayıncılık. 